\title{
Ewa Cichowicz
}

Warsaw School of Economics

Collegium of Socio-Economics

Institute of Social Economy

e-mail: ewa.cichowicz@sgh.waw.pl

\section{The use of modern technology by financial institutions in combating financial exclusion"}

\begin{abstract}
Financial exclusion can be considered as one of the important problems in countries at the average level of socioeconomic development that include, among others, Poland. It consists in the presence of difficulties in accessing and/or using financial products and services available on the main market that meet the needs of individuals, which prevents them from leading a normal life in society. Due to its own characteristics and trends in financial markets, this phenomenon is closely linked to the issue of the digital divide. Accordingly, it can be seen that solutions leading to the reduction of financial exclusion are based on tools using information technology innovations and modern technologies. One of the methods recognised as the most effective in this area is financial education, aimed largely at children and adolescents, which additionally justifies the choice of such tools. It is equally important to determine the extent to which modern instruments are preferred in comparison with traditional ones. The aim of this paper will be the analysis of the solutions based on modern technologies that are used in actions taken to prevent financial exclusion in selected EU countries, including Poland. The structure of the paper is as follows: the first part will present the problem of financial exclusion (identifying groups particularly at risk), then a review of methods of preventing and combating financial exclusion will be presented, with particular emphasis on modern ICT tools, and the final part will indicate possible
\end{abstract}

\footnotetext{
* The article is an updated version of the paper published in Polish in the Annales. Ethics in Economic Life, 19(1), 71-82.
} 
directions and barriers to the solutions that may lead to a reduced level of financial exclusion of individuals. The methods used include an in-depth analysis of the literature and a review of existing solutions which financial institutions provide on the Web.

Keywords: financial exclusion, financial education, Information and Communication Technologies (ICT)

JEL Classification: D14, G21, O33

\section{Introduction}

Financial exclusion and development of modern technologies are phenomena whose significance and impact on contemporary socio-economic systems (perceived from the perspective of individuals as well as society) are constantly growing. It is worth emphasising that these issues are closely related. Observation of trends in the financial markets (not only in highly developed countries but also in countries at the average level of socio-economic development such as Poland) allows one to state clearly that products and services offered by financial institutions are increasingly complex. In addition, along with the increase in complexity, the ways of their distribution and promotion are changing, becoming increasingly based on the use of modern technologies. These processes contribute to the intensification of financial exclusion and create the situation in which individuals (groups of individuals) who have problems with access to the Internet or using tools based on modern technologies are particularly exposed to this type of exclusion, which leads to further negative implications. It is noteworthy that one of the most important methods of combating financial exclusion and limiting its adverse consequences is financial education and actions to improve the level of financial literacy. Significantly, these solutions are often implemented through the Internet or applications that utilise remote access to resources. The question arises whether the modern technologies can aid in preventing financial exclusion.

The aim of the article is to analyse how the solutions based on modern technologies can influence the formation, scale and intensity of the financial exclusion in Poland as a European Union country characterised by a relatively high level of financial exclusion (European Commission, 2012, p. 13). Particular attention has been paid to economic education, to which unusually broad possibilities not only to combat financial exclusion but also to support the processes of financial inclusion are attributed. The article assumes that this type of education and related activities are an effective tool that in a long-term perspective may permanently reduce financial exclusion and, above all, its negative effects in countries characterised by at least the average level of socio-economic development. This refers to a situation in which only a small percentage of the population would be affected. 
On the other hand, one should not overlook issues related to the implementation by banks of new tools that help individuals in their access to financial products and services and create better opportunities to use them. Although the purpose of their introduction is often not to combat financial exclusion, they actually lead to the reduction in the level of this phenomenon.

The article is divided into three parts. The first part presents the issue of financial exclusion with its specific features. This section also includes a brief description of the groups most exposed to this type of exclusion. The second part presents a review of the methods that contribute to counteracting and combating financial exclusion. Particular attention is paid to the tools based on IT innovations and modern technologies. The considerations are also extended to include possible barriers to taking action in this area. The final section is devoted to the conclusions of the present analysis.

The article is based on an in-depth analysis of the available literature, specifically relating to Poland where the banking penetration ratio is lower than in other European Union countries. ${ }^{1}$ It is supplemented with a review of existing solutions (including their evaluation) based on the analysis of the content of websites of individual financial institutions and other entities whose activities are related to the financial market. Therefore, the article is mainly theoretical in nature.

\section{Financial exclusion-its nature and specificity}

Financial exclusion can be defined as a phenomenon related to a situation in which individuals have problems with access and/or use of services and financial products available on the so-called mainstream (regulated by law) market that meet their needs, enabling them to lead a normal life as members of society (European Commission, 2008, pp. 9-10). This means that some people cannot fully fulfil their financial needs (and thus, indirectly, also other needs that are associated with the flow of financial resources) due to the existence of barriers of a nonnatural nature (e.g.: a lack of resources that can be allocated to savings) and barriers created by financial institutions (e.g.: too high demands placed on a group of potential clients considered unattractive or potentially unreliable by financial institutions). ${ }^{2}$ In addition, it is worth mentioning people referred to in the discourse as self-excluded persons. This group is divided into two categories of individuals:

\footnotetext{
${ }^{1}$ The banking penetration ratio can be understood as a concept that relatively well reflects the level of availability of banking products and services. Although in the literature this term is not clearly defined, the banking penetration ratio is usually described by means of indicators determining the degree of use of the bank offer by individuals (including, in particular, taking into consideration the number of bank accounts or payment cards held, and less frequently-savings products, loans and insurance) or the number of branches of financial institutions or cash dispensers per a given number of inhabitants. Cf. analyses carried out by the National Bank of Poland (e.g. Koźliński, 2009) or publications and resources made available by the World Bank (e.g.: Demirguc-Kunt \& Klapper, 2012).

${ }^{2}$ The reasons for financial exclusion are usually divided into demand, supply and social ones (cf. European Commission, 2007).
} 
those who are not willing to participate in financial market processes and those who are not aware of how and why they could or should participate in this market. Regardless of the reasons for their lack of using financial products and services, the presence of modern technologies is an important factor, on the one hand, determining the decisions of these people in the sphere of personal finance management, and on the other, enabling them to take actions as financial market participants.

Due to their specificity, several social groups are primarily exposed to financial exclusion. It should be noted that although each of them is characterised by different special features, often the criteria for belonging to these categories overlap (these people can be assigned to more than one group). The following persons are particularly threatened by financial exclusion (cf. Alińska, 2011, p. 11; Szopa \& Szopa, 2011, p. 20):

(1) with low economic status,

(2) with a low level of education,

(3) elderly (50+),

(4) from rural areas,

(5) disabled,

(6) having a certain set of specific psychological features that constitute a strong disincentive to the use of the financial market (e.g.: fears of modern technologies or the habit of cash payments),

(7) young persons, including those inheriting the financially excluded status, but also those who do not have a "history" of cooperation with financial institutions. $^{3}$

In the case of each of the above-mentioned groups, particularly vulnerable to financial exclusion, it is possible to distinguish a specific set of conditions that contribute to the difficulties in access and use by those individuals of financial market products and services. For example, people with low economic status tend to be a group of unattractive clients (cf. Błędowski \& Iwanicz-Drozdowska, 2010, pp. 8-9). This explains a general lack of offer specifically addressed to these groups of people. The "standard" conditions are often out of their reach and too costly. Poorly educated people are often unable to make the optimal choice for themselves, which, for example, results in incurring too high (sometimes even unnecessary) costs for an offer not suited to their needs. Problems in their case may also be related to electronic and mobile banking, where all the activities must be done by customers, without the participation and possible help of the staff of a given financial institution. On the one hand, seniors perceive the financial sector as dangerous (associated with a possible loss of funds), on the other hand, they treat the personnel of financial institutions as trustworthy, which means that they buy products that they do

\footnotetext{
${ }^{3}$ It should be remembered that the situation of young people should be considered from two perspectives. On the one hand, the offer is often directed to them, and products and services are adapted to preferences of students and people starting their careers. Banks treat them as prospective clients, even if they do not constitute a profitable group in a given period. On the other hand, the group of financially excluded (or those at risk of this type of exclusion) young people is relatively heterogeneous. An additional factor leading to their exclusion is undoubtedly their background and the environment from which they come (understood both in terms of their socio-economic status and territorial status).
} 
not need or they do not read contracts, which in turn translates into their later reluctance to use the financial offer. At the same time, digital exclusion is a major problem for elderly people (Kubicki, 2013, pp. 44-47). According to the data of the Ministry of Administration and Digitisation, approx. 70\% of Poles over the age of 50 do not use the Internet (Kapiszewski, 2014, p. A5). Data from the National Bank of Poland survey conducted in 2011-2012 regarding payment habits of Poles (Koźliński, 2013, p. 96) indicate that among bank account holders, 24\% are 65 years old or older. Only half of the respondents in the 55-64 year age group have access to online banking. In the case of senior citizens, financial exclusion of people living in rural areas and in small towns depends, to a large extent, on their lack of access to the Internet ${ }^{4}$, which makes it impossible to use the electronic offers provided by the financial institutions. The problem is compounded by the lack of a sufficient number of bank branches and cash dispensers located outside larger urban agglomerations. The situation is different, however, in the case of disabled people (Gajda, 2010), for whom e-banking can be a factor of an inclusive nature in terms of participation in the financial market (provided that websites are adapted to the capabilities of these clients - primarily people with visual impairments). If, on the other hand, the group of young people is to be seen as particularly vulnerable to financial exclusion, the main characteristics will certainly be: the relatively low percentage of use of financial products and services by people under 24 (which, however, is well justified by low demand due to their age) and the relatively frequent use of this offer via remote channels (cf. Gajda, 2010, pp. 24, 95). In the group of young people, however, the key issue is a lack of adequate knowledge and financial literacy. The skilful use of these attributes would make it possible to avail of the offer in a conscious, rational manner and adequately to existing needs, and thus should result, among others, in the reduction of the risk of later financial problems of such a person.

Thus, it can be noted that the process of financial exclusion is determined by many factors, the most important of which are those of a social, economic, legal and territorial nature (Ziemba, Świeszczak \& Marcinkowska, 2014, p. 146). In addition, they include the factor associated with the dynamic development and use of modern technologies on a wider scale.

\section{Modern technologies and counteracting financial exclusion}

The use of modern technologies by financial institutions in the light of the process of counteracting financial exclusion can be analysed taking into consideration several aspects. It should be emphasised that the relationship between the implementation of technological innovations and activity in the area of combating financial exclusion depends on the entity that chooses the solutions in the framework of its business activities and formulated objectives.

\footnotetext{
${ }^{4}$ However, it should be noted that according to the data presented in the survey carried out at the request of the NBP, $28 \%$ of people from rural areas do not have a bank account at all (cf. Koźliński, 2013, p. 25).
} 
One should point to the activities in the field of broadly understood financial education that are conducted by various institutions - financial and non-financial, commercial and non-commercial, with a national and international scope. ${ }^{5}$ The review of websites shows that these initiatives (especially when taken by financial institutions) are to a large extent based on modern tools that require an Internet connection. The National Bank of Poland has been running the NBPortal Internet platform for over ten years ${ }^{6}$ to disseminate knowledge about the market economy, the rules regarding the functioning of financial markets, and to cultivate appropriate attitudes. Its goal is to bring the economic knowledge to children, the young adults, teachers, seniors and people with disabilities. On the websites of the central bank and other commercial banks (those which, in the framework of the implementation of the concept of Corporate Social Responsibility or socially engaged marketing, conduct activities aimed at increasing financial literacy), there are numerous online games, quizzes, interactive simulations and multimedia presentations. This trend is similar to the directions of initiatives undertaken by the banking sectors in the other European Union countries, such as the central bank of Germany ${ }^{7}$ or Lithuania. ${ }^{8}$

The use of modern technologies (not only as part of activities in financial education, but also within the basic activity carried out by financial institutions) is a factor encouraging above all young people (up to 24 years of age) and persons who in everyday life (including their professional life) use similar tools. In the case of these customer groups, the lack of electronic banking in the institution's offer may lead to the self-exclusion decision.

The financial institutions are creating and offering free applications that are easy to use to manage one's money. For instance, applications that teach how to save money develop positive saving habits. These applications, due to the simplicity of their use and their attractive form, are an effective response to the needs of people with a low educational level whose intellectual capabilities to predict the consequences of, for instance, borrowing large sums may be limited. ${ }^{9}$ The problem, however, is a lack of knowledge about the existence of such applications. The target groups (due to their earlier exclusion by financial institutions or because of self-exclusion) may be unaware of the services and the financial products available to them.

\footnotetext{
${ }^{5}$ These institutions include in particular: commercial and cooperative banks, associations of commercial banks, foundations operating at commercial banks, central banks, the European Commission, the Organisation for Economic Cooperation and Development, the European Financial Inclusion Network and nongovernmental organisations (e.g.: the Microfinance Centre, the Association of Third Age Universities or the Rural Development Foundation). The term "conducting activities" is also understood in this sentences as implementing directives and developing recommendations or creating legal conditions, and not only implementing specific programmes, which result in reducing the level of financial exclusion.

${ }^{6}$ The content of this platform is available at the following address: http://www.nbportal.pl/.

${ }^{7}$ In addition to numerous interactive materials, the interactive Museum of Money can also be such an example: http://www.bundesbank.de/Navigation/DE/Bundesbank/Geldmuseum/geldmuseum.html.

${ }^{8}$ On the bank's website, one can, among others, find multimedia materials, and bank employees organise on-line training: http://www.lb.lt/education.

${ }^{9}$ It should be taken into account that these individuals have difficulties using the computer and the Internet in general (cf. Czapiński \& Panek, 2014, pp. 377-378), however, the level of complexity of programmes facilitating the management of personal finances is minimal.
} 
The financial institutions are also using similar technologies to reach and serve the people with hearing, vision, and motor skills. The elderly, especially with various disabilities may have similar needs and expectations regarding the financial products and services. ${ }^{10}$ For those with mobility difficulties, the possibility of using financial services via remote channels within the electronic banking framework cannot be overestimated. However, to obtain access to these services, one usually has to visit a bank branch. The banks are increasingly being remodelled to accommodate the needs of such people. In highly developed countries such as France, one may find special buttons placed outside the door to call an employee who will help the disabled. For people with visual and hearing impairments, the issue related to the use of websites (e.g. adjusting the font size or contrast as well as client authorisation mechanisms) ${ }^{11}$ and the diversification of devices that support applications such as telephone banking are important. Interestingly, the banks operating in Poland are reluctant to adapt their websites to the needs and expectations of people with disabilities. The disabled citizens in Poland, more so than other social groups, are affected by digital exclusion that prevents them from accessing and using products and services offered in the financial market.

The reduction of digital exclusion is also one of the essential premises for counteracting financial exclusion that has a territorial basis. It seems that the development of electronic banking is more justified from the point of view of financial institutions in terms of incurred costs and investment efficiency. According to contemporary trends, banks are spending more and more money on broadly understood universal electronic banking. This translates indirectly into the number of bank branches opened. Therefore, people from less urbanised areas can quickly meet their financial needs by means of video-conferencing. It is worth emphasising that such solutions supported by numerous initiatives in financial education. Equipping the rural libraries with computers and the Internet, providing training in personal finance management, and using various forms of communication are some of the ways of getting people interested in entering the sphere of electronic banking or just economic and financial issues. ${ }^{12}$

The latest in the digital technology are the biometrics devices. Digital biometric tools are quick and reliable ways for authentication of clients and authorisation of transactions based on individual personal characteristics such as fingerprints, finger or hand veins, the pupil pattern, or voice recognition (Kuchciak, 2011, p. 226). Since such technology is new and arrived in Poland in 2010 when Podkarpacie Bank Spółdzielczy installed a biometric cash dispenser,

\footnotetext{
${ }^{10}$ This does not refer, however, to the type of products and services or the criteria that must be met in order to be able to use them.

${ }^{11}$ For example - the need to adapt tokens to the needs of the blind or introduce a different verification method than a one-time code card (cf. http://di.com.pl/oferty-bankow-w-sieci-a-niepelnosprawni34032).

${ }^{12}$ Such initiatives include: the Library Development Programme, implemented throughout the country in more than 3,800 libraries in small towns: http://www.biblioteki.org/pl/o programie/o programie, or the project co-financed by the National Bank of Poland "On finance in the library" (http://www.biblioteki.org/repository/PLIKI/O_FINANSACH/opis_projektu.doc).
} 
(https://www.pbsbank.pl/biometria1), it is possible to indicate only some of its applications. Thanks to biometrics, one no longer needs identity cards for customer verification, nor is it necessary to memorize passwords, or personal identification numbers (PIN) - often the problems with the elderly and those with lower social status. Using biometrics, it is also easier to establish the credibility of an individual, based on his or her history of cooperation with financial institutions, which could contribute to a more reliable assessment of a given client. Another example (used in Poland) is the streamlining of the payment of social benefits to the entitled persons improving the quality of service, security, and reducing the waiting time (Woszczyński, 2013, pp. 48, 50).

Based on the review of presented methods and tools, it can be seen that the use of modern technologies in financial institutions is very extensive. Their role in the process of combating financial exclusion is significant, and it can be assumed that this role will continue to grow. Importantly, financial sector institutions themselves are interested in developing this type of innovations. An additional advantage of modern technologies is the fact that they can be applied to different groups of individuals who are particularly threatened by the process of financial exclusion. At the same time, it should be noted that Poles declare very high confidence in innovative technologies and the level of security of transactions concluded via the Internet ${ }^{13}$, and the level of these services offered by financial institutions in Poland is also high, which may additionally facilitate their development and effectiveness in combating financial exclusion.

\section{Conclusions}

Thus far, due to the limited access to the IT networking in Poland, a lack of computers or devices that allows electronic banking and a lack of knowledge about using such tools a relatively high percentage of households is deprived of access to financial products and services via the Internet. ${ }^{14}$ This is all the more significant since the financial institutions increasingly prefer the individuals to contact and make transactions through remote communication channels, which is manifested, among others, in diversifying the level of prices of products and services. These barriers are particularly visible in the case of the elderly; however, they also apply to residents of rural areas (and poorly urbanised areas) as well as to people with low incomes and low education levels. Seniors are often reluctant to use modern solutions that are too dynamic for them, and sometimes also require too much

\footnotetext{
${ }^{13} \mathrm{Cf}$. https://www.deutschebank.pl/biuro-prasowe/raporty-i-analizy/kategoria-materialy-analityczne/ deutsche-bank-research-polacy-ufaja-bankowosci-elektronicznej.html.

${ }^{14}$ According to the Social Diagnosis (Czapiński \& Panek, 2014, pp. 357, 367) data for 2013, approx. $30 \%$ of households did not have a computer and approx. $33 \%$ of households had no Internet access, additionally a lack of Internet skills was the reason for a lack of access to the Web for approx. 25\% of households, and finally approx. $15 \%$ of households that had the Internet did not use it.
} 
precision (e.g.: in the case of using touch screens) or remembering a number of passwords.

On the other hand, as a result of adapting technology to the declared needs of individuals (potential clients) so as to encourage them to use the widest possible offer of financial institutions, many methods to facilitate access to products and services are being introduced. For example, the use of biometrics, which results in no need to memorise passwords, faster and more comprehensive verification of the credibility of the client, and even in eliminating the presentation of documents confirming one's identity. In addition, there are numerous manuals and guides (in various forms) on how to use the proposed tools. At the same time, the impact of a demographic factor cannot be overlooked. A generational change is taking place, as a result of which individuals entering old age are already able to use modern technologies (among others, because they used such technologies during their professional career). For people of working age, solutions based on modern technologies constitute a significant facilitation in everyday functioning, additionally limiting transaction costs. Moreover, multimedia applications are attractive also for the young generation, for whom the use of the Internet is very often an important part of life, thanks to which (in conjunction with numerous programmes of financial education addressed to youth and young adults) acquiring knowledge in the field of economics and finance by this generation is easier and is done more readily.

On the basis of the considerations carried out in the text, it seems justified to state that modern technologies should be included among factors that exert both a positive and negative influence on the level of financial exclusion. However, observing trends in socio-economic systems at the average and high level of development, as well as demographic phenomena and processes along with activities undertaken by institutions related to the financial sector (or affecting it), it can be assumed that the first of these trends should gradually become dominant. This should also be facilitated by the fact that technological innovations, due to their nature, are very flexible in adapting to the needs of both financial institutions and their clients (current and potential).

\section{References}

Alińska, A. (2011). Problem wykluczenia finansowego w Polsce. Zeszyty Naukowe Uniwersytetu Szczecińskiego, 682, 9-22.

Błędowski, P., \& Iwanicz-Drozdowska, M. (2010). Wykluczenie finansowe w Polsce a możliwości przeciwdziałania. Polityka Społeczna, 2, 5-10.

Cichowicz, E. (2016). Wykorzystanie nowoczesnych technologii przez instytucje finansowe w procesie przeciwdziałania wykluczeniu finansowemu. Annales. Ethics in Economic Life, 19(1), 71-82 
Czapiński, J., \& Panek, T. (Eds.). (2014). Diagnoza Społeczna 2013. Warunki i jakość życia Polaków. Warszawa: Ministerstwo Pracy i Polityki Społecznej and Centrum Rozwoju Zasobów Ludzkich. www.diagnoza.com

Demirguc-Kunt, A., \& Klapper, L. (2012). Measuring Financial Inclusion: The Global Findex Database. World Bank Policy Research Working Paper, No. 6025. https://openknowledge.worldbank.org/handle/10986/6042

European Commission. (2007). Wykluczenie finansowe - zapewnienie odpowiedniego dostęu do podstawowych ustug finansowych [Information based on the analysis "Financial services provision and prevention of financial exclusion" prepared by the European Commission]. http://ec.euro pa.eu/social/BlobServlet?docId=4574\&langId $=$ pl

European Commission. (2008). Financial Services provision and prevention of financial exclusion. http://www.fininc.eu/gallery/documents/final-report2007-and-summary/financial-services-provision-and-prevention-of-financialexclusion-final-report.pdf

European Commission. (2012). Special Eurobarometer 373, Retail Financial Services. http://ec.europa.eu/public_opinion/archives/eb_special_379_360_en. htm\#373

Gajda, M. (2010, December 14). Niepetnosprawni finansowo wykluczeni. http:// www.niepelnosprawni.pl/le dge/x/78834

Kapiszewski, J. (2014, November 10 ). Komputer mieczem w walce o pracę. Dziennik Gazeta Prawna, 219.

Koźliński, T. (Ed.). (2009). Porównanie wyników badań ubankowienia Polaków przeprowadzonych przez NBP w 2006 i 2009 r. Warszawa: NBP. http://www.nbp.pl/systemplatniczy/obrot_bezgotowkowy/ubankowienie_p olakow.pdf

Koźliński, T. (Eds.). (2013, May). Zwyczaje płatnicze Polaków. Warszawa: Narodowy Bank Polski. http://www.nbp.pl/systemplatniczy/zwyczaje_plat nicze/zwyczaje_platnicze_Polakow.pdf

Kubicki, P. (Ed.). (2013). Osoby starsze na rynku usług finansowych. Analiza i zalecenia. Biuletyn RPO, 4. http://www.brpo.gov.pl/sites/default/files/132 79229450_0.pdf

Kuchciak, I. (2011). Bankowość biometryczna - nowe wyzwanie dla polskiego sektora bankowego. Annales Universitatis Mariae Curie-Skłodowska. Sectio H, Oeconomia, 45(2), 225-233.

Szopa, B., \& Szopa, A. (2011). Wykluczenie finansowe a wykluczenie społeczne. Zeszyty Naukowe PTE, 11, 13-27.

Uryniuk, J., (2012). Aplikacje do zarządzania budżetem domowym coraz bardziej popularne. Gazeta Prawna. http://serwisy.gazetaprawna.pl/finanse-osobiste/ artykuly/606230,aplikacje_do_zarzadzania_budzetem_domowym_coraz_bar dziej_popularne.html 
Woszczyński, T. (Ed.). (2013). Raport Biometryczny 2.0: Bankowość biometryczna. Warszawa: Grupa FTB ds. Biometrii.

Ziemba, M., Świeszczak K., \& Marcinkowska, M. (2014). Wykluczenie finansowe osób 50+ w kontekście dostępnej oferty bankowej. Finanse, 1(7), 145-170.

http://di.com.pl/oferty-bankow-w-sieci-a-niepelnosprawni-34032

http://www.biblioteki.org/pl/o_programie/o_programie

http://www.biblioteki.org/repository/PLIKI/O_FINANSACH/opis_projektu.doc

http://www.bundesbank.de/Navigation/DE/Bundesbank/Geldmuseum/geldmuseu m.html

http://www.lb.lt/education

http://www.nbportal.pl/

https://www.deutschebank.pl/biuro-prasowe/raporty-i-analizy/kategoria-materialyanalityczne/deutsche-bank-research-polacy-ufaja-bankowosci-elektronicznej.html

https://www.pbsbank.pl/biometrial 